Embodying the Problem 



\section{Embodying the Problem}

The Persuasive Power of the Teenage Mother

JENNA VINSON

\section{iid}

Rutgers University Press

New Brunswick, Camden, and Newark, New Jersey, and London 
Library of Congress Cataloging-in-Publication Data

Names: Vinson, Jenna, 1984- author.

Title: Embodying the problem : the persuasive power of the teenage mother / Jenna Vinson. Description: New Brunswick : Rutgers University Press, [2017] | Includes bibliographical references and index.

Identifiers: LCCN 2017020839 (print) | LCCN 2017011494 (ebook) | ISBN 9780813591018 (cloth : alk. paper) | ISBN 97808 1359100I (pbk. : alk. paper) | ISBN 9780813591025 (epub) | ISBN 9780813591049 (Web PDF)

Subjects: LCSH: Teenage mothers-United States.

Classification: LCC HQ759.4.V56 2017 (ebook) | LCC HQ759.4 (print) |

DDC $306.874 / 3-\mathrm{dc} 23$

LC record available at

https://lccn.loc.gov/2017020839

A British Cataloging-in-Publication record for this book is available from the British Library.

Copyright ( 2018 by Jenna Vinson

All rights reserved

No part of this book may be reproduced or utilized in any form or by any means, electronic or mechanical, or by any information storage and retrieval system, without written permission from the publisher. Please contact Rutgers University Press, I06 Somerset Street, New Brunswick, NJ 0890 I. The only exception to this prohibition is "fair use" as defined by U.S. copyright law.

The paper used in this publication meets the requirements of the American National Standard for Information Sciences-Permanence of Paper for Printed Library Materials, ANSI Z39.48-1992.

www.rutgersuniversitypress.org

Manufactured in the United States of America 
For my mother, Beth 
